\title{
Tiede ja edistys
}

Tiede ja edistys -lehti on ollut olemassa kaksi vuotta; tähän mennessä on ilmestynyt kahdeksan numeroa eli kaksi vuosikertaa.

On hyvä tilaisuus tehdä yhteenvetoa tähänastisesta sisällöstä ja arvioida saavutettua. Tämä on myös tarpeellista. Tulevaisuuden pohjaksi on verrattava toisiinsa toteutunutta sekä niitä suunnitelmia, joita tehtiin hiukan yli kaksi vuotta sitten lehden ensimmäisiä numeroita koottaessa. Todettakoon heti alkajaisiksi: Tähänastisten kokemusten arvioinnille antaa rohkaisevan lähtäkohdan se, että lehti on otettu hyvin vastaan. Sen lukijakunta on laajentunut. Sen sisällöstä käydään runsaasti keskustelua, mikä on tavattoman tärkeätä, ja johtopäätöksiä kantautuu toimituksenkin tietoon. Samalla lisättäköön edellä sanottuun: Toimitus ei kirjaa ainoastaan positivisia arvioita vaan myös negatiivisia - niitä, jotka antavat tehtäviä lehden kehittämiselle. Myös näitä toivotaan, ja myös näitä on saatu.

Lehtemme toimituksellisen linjan perusajatus ilmenee jo nimestä: Nojaamme siihen perusvakaumukseen, että tieteellinen edistys ja yhteiskunnallinen edistys kuuluvat yhteen. Tämän perustana ovat tieteen kehityksen ja yhteiskunnallisen kehityksen historia ja lainmukaisuudet. Yhteys on hyvin monitahoinen, sitä ei voi pelkistää yksinkertaiseen kaavaan. Mutta samalla tämä yhteenkuuluvuus on todellinen, päivittäin korostuva ja hyvinkin konkreettinen. Rauhantaistelu, neutronipommin ja muiden joukkotuhoaseiden vastustaminen, aseriisunta, sorron ja sitä oikeuttavien aatteiden torjuminen; nämä ja monet muut ovat tehtäviä, jotka nousevat tänä päivänä yhä voimakkaammin esiin sekä tieteen että yhteiskunnan kehityksen perusedellytyksinä.

Jos tieteen ja edistyksen monitahoisesta yhteydestä halutaan nostaa esiin jokin erityinen, lehdellemme tärkeä momentti, niin tällainen on epäilemättä t i e te e 11 i n e $\mathrm{m}$ a a i $1 \mathrm{~m}$ a $\mathrm{n} \mathrm{a}$ t s o m u s. Olennaista on, että tieteellinen maailmankatsomus on yhtenäinen. Tähän perustuu mahdollisuus tehdä lehteä, joka kattaa kaikki alat ja on luonteeltaan tieteellinen. Kysymys ei ole eri alojen tulosten sekasotkusta, ei myöskään kuvitelmasta, että eri tieteenalat voitaisiin korvata ja niiden ongelmat ratkaista vedoten jonkinlaisen "yleistieteen" oikotiehen. Kysymys on siitä, että tieteellinen maailmankatsomus tarvitsee rakennusaineekseen kaksi osaa: yhtäältä erityistieteiden tärkeimpien, perustavimpien tulosten tuntemuksen, toisaalta eri alojen yleistykset ja yleiset johtopäätökset, joiden soveltaminen juuri tekee maailmankatsomuksesta tieteellisen.

Ehyen tieteellisen maailmankatsomuksen välttämättömyys käy yksiin tieteen vaatimusten kanssa. Onko tämä väite ristiriidassa sen kanssa, että jo pitkään tieteen kehityksen vallitsevana suuntana on ollut eri alojen eriytyminen toisistaan, tutkimuksen kasvava spesialisoituminen? Ei suinkaan. Myös erityistieteiden omien tutkimusongelmien tasolla ilmenee voimakkaana yhtenäisyyden vaatimus. Eri tieteenalojen tulosten vertailu ja metodiset yleistykset ovat lisänneet merkitystään. 
Tieteellisen maailmankatsomuksen välttämättömyys yhteiskunnallisen edistyksen puolustamiselle on selvä. Tehtävänähän on yhteiskunnan tietoinen uudistaminen. Tätä ei voi edes asettaa tehtäväksi muuten kuin tieteeseen nojautuen.

Tieteen ja edistyksen kahdeksan ensimmäisen numeron artikkeliosastoihin on sisältynyt vhteensä 48 nimikettä. Näiden aihepiirit ovat kattaneet laajan alueen, jonka eräänlaisina ääripäinä voi ottaa esiin vaikkapa seuraavat: luonnontieteen tärkeimpien teorioiden kehitys (evoluutioteoria 3/77, 2/78, suhteellisuusteoria 3/78), filosofia (Spinozan ajankohtaisuus $1 / 77$ ), yhteiskuntatieteen teorioiden kehitys (Leninin "Imperialismin" syntyhistoria 1/76, keynesiläisyyden kriisi 1/78), korkeakoulu- ja tiedepolitiikan keskeiset kysymykset (korkeakoulukysymys $1 / 76$, koulutus- ja tiedeyhteisön autonomia $1 / 78$, Suomen ja Neuvostoliiton tiedeyhteistyö 2/78), Suomen työväenliikkeen tutkimusperinne (Timo Kosten haastattelu 1/76), ajankohtaisten poliittisten kysymysten taustan erittely (ETYK ja kansainvälinen oikeus 2/77, Suomen talouden rakennekriisi $2 / 78$, uusi kansainvälinen talousjärjestys $2 / 78$ ), politiikan teoria (leninismi metodina 3 /77).

Tämä luettelo saattaa vaikuttaa hajanaiselta. Mutta artikkeleiden yhdistävänä tekijänä on, toistettakoon se vielä, tieteellinen maailmankatsomus. Tietenkin eri alojen artikkeleiden anti on erityyppinen. Ne onnistuvat eri tavoin, toisesta saa enemmän kuin toisesta jne. Mutta nämä ovat ongelmia, jotka eivät koske lehden linjaa, vaan sen toteutumisen yksityiskohtia.

Pyrkimyksemme on kehittää Tiede ja edistys -lehteä sisällöltään vielä monipuolisemmaksi. Eräiden alojen suhteen on vielä avauskin suorittamatta. Koko tekniikan alaa on käsitelty hyvin vähän, samoin ovat toistaiseksi puuttuneet monet oman maamme tieteellisessä elämässä perinteisesti merkittävällä sijalla olleet humanistisen tutkimuksen sektorit (kielitiede, perinnetieteet). Näiden vuoro varmasti tulee.

Tiede ja edistys -lehden linjan perustana on tieteellisen sosialismin teoria. Kannattaa toistaa Leninin vaateliaat sanat artikkelista "'Marxismin kolme lähdettä ja kolme perusosaa": "Marxin oppi on kaikkivoipa, sillä se on oikea. Se on täydellinen ja johdonmukainen, se antaa ihmisille eheän maailmankatsomuksen, joka ei sopeudu yhteen minkään taikauskon, minkään taantumuksen, minkään porvarillisen sorron puolustelujen kanssa. Se on kaiken sen parhaan laillinen perijä, minkä ihmiskunta loi 19. vuosisadan saksalaisen filosofian, englantilaisen taloustieteen ja ranskalaisen. sosialismin muodossa." Samalla lähdemme siitä, että myös muu kuin tietoisesti marxilainen tutkimus voi olla ja hyvin usein on edistyksellistä. Lehtemme on avoin kaikille niille, jotka asennoituvat tieteellisyyden ja yhteiskunnallisen edistyksen puolesta.

Eräs olennainen ongelma lehdellemme on luonnollisesti artikkeleiden luettavuus. Vaatimukset ovat tässä suhteessa suuret. On kyettävä yhdistämään toisiinsa tieteellisyys ja helppotajuisuus. Olemme tietoisia siitä, että juuri tämän vaatimuksen suhteen on esitetty runsaasti aiheellista kritiikkiä. Lehtemme kir- 
joittajat ovat usein kokeneita sanankäyttäjiä, kuten tutkijat ovat. Mutta kokemus on kertynyt erilaisilla foorumeilla. Tiede ja edistys -lehti vaatii oman kirjoittamistyylinsä, oman kirjoittamisperinteensä kehittämistä. Tämä ei ole helppo tehtävä, vaan edellyttää systemaattista työtä, jossa toimituksen ja lehden lukijoiden yhteistyö voi olla suureksi avuksi. Otamme mielihyvin vastaan hyvinkin yksityiskohtaisia tiettyihin artikkeleihin, niiden sanontaan, esitystapaan ja tyyliin liittyviä huomautuksia opiksi otettavaksi ja tulevan kehityksen turvaamiseksi.

Lehtemme tulevaisuuden suunnitelmat voi kiteyttäå neljään määreeseen, jotka ovat pysyvänä ohjenuorana:

- Tiede ja edistys on ajankohtainen: Se erittelee yhteiskunnallisessa elämäsaineiston tieteellisyyden vaatimuksesta.

- Tiede ja edistys on kriittinen: Se arvostelee porvarillisen tutkimuksen tuloksia ja muotiteorioita.

- Tiede ja edistys on ajankohtainen: Se erittelee yhteiskunnallisessa elämässä ja keskustelussa esillä olevien ilmiöiden taustaa.

- Tiede ja edistys on keskusteleva: Se julkaisee keskustelupuheenvuoroja ja erilaisia näkemyksiä tieteellisistä ongelmista sekä marxilaisten ja muiden edistyksellisten tutkijoiden ajatusten vaihtoa.

Artikkeliosaston ohella kehittämisen tehtäviä asettaa luonnollisesti petiittipuoli: "Esittelyjä ja erittelyjä" sekä "'Tieteellinen elämä". Näille on asetettu kaksi selvää tavoitetta. Ensinnäkin pyrimme julkaisemaan tiedepoliittisen aineiston lisäksi entistä enemmän tutkimuksellista aineistoa: raportteja tärkeistä tieteellisistä kokouksista, esittelyjä ja arvioita ilmestyvistä tutkimuksista jne. Toiseksi pyrimme lisäämään osastojen ajankohtaisuutta, ilmestyvän kirjallisuuden nopeata seurantaa ja esittelyä sekä keskustelussa esillä olevien asioiden kommentointia.

Tiede ja edistys -lehti lähtee kolmannelle vuodelleen optimismin saattelemana. Joissakin yhteyksissä lehdestä on käytetty nimitystä "uuden tyypin tieteellinen aikakauslehti". Nimitys on oikeutettu — vastaavaa lehteã on vaikea löytää. Nimitys antaa suuria haasteita. Lehden toimitus katsoo voivansa ottaa aktiivisen ja yhteyksiä ylläpitävän lukijakunnan tuella haasteet vastaan. 


\section{Tässä numerossa}

Nykyisen monopolikapitalismin ja valtiomonopolistisen kapitalismin keskeisiä piirteitä on valtion roolin kasvu ja korostuminen järjestelmän uusintamisessa. Tämä kehitys on haaste myös marxilaisen politiikan teorian kehittämiselle ja marxilaiselle teorialle valtiosta porvarillisessa yhteiskunnassa. Kansainvälisessä keskustelussa nämä ongelmat ovat jatkuvasti ajankohtaisesti esillä. Tämän numeron teemaksi olemmekin valinneet politiikan teorian, jota koskettelevia artikkeleita julkaisemme kolme.

Kari Toikka erittelee artikkelissaan poliittisen hallitsemistavan käsitettä, jonka avulla hän pyrkii jäsentämään marxilaisen politiikan teorian eräitä keskeisiä ja ongelmallisia kysymyksiä. Poliittisen hallitsemistavan käsitteen täsmentämisen kautta Toikka etenee tarkastelemaan Suomen poliittisen järjestelmän kehitystä II maailmansodan jälkeen, missä yhteydessä keskustellaan myös TANDEM-työryhmän raportissaan "Demokratian rajat ja rakenteet" esittämästä tulkinnasta Suomen politiikan jäsentämisen suhteen.

Markku Kivinen puolestaan tarkastelee kirjoituksessaan sellaiseen marxilaiseen valtioteoriaan ja politiikan teoriaan liittyviä ongelmia, joka pyrkii suorittamaan valtion muotomääritysten "yleisen johdon" Marxin "Pääomassa" esittämän poliittisen taloustieteen kritiikin sisällä. Keskeisenä ongelmana on tällaisen tutkimusotteen rajojen määrittely.

Kolmas politiikan teoria -teemaan liittyvä artikkeli on Matti Piispan kirjoittama ja se käsittelee politiikan teorian - jos niin voi sanoa - ideologista puolta. Piispa käsittelee erästä tärkeätä porvarillisen herruuden legitimoinnin muotoa, pluralistista demokratiateoriaa. Osoittamalla sen synnyn juuret kapitalistisessa yhteiskuntamuodossa Piispa tarkastelee ns. intressiryhmäteoriaa eräänä pluralismiteorioiden muotona. (Tässä numerossa julkaisemme myös "Esittelyjä ja erittelyjä" -osastossa politiikan teoriaan liittyviä kirjoituksia.)

Pekka Sutela puolestaan on artikkelissaan ottanut tarkastelun kohteeksi erityisesti poliittisessa keskustelussa ajankohtaiseksi nousseen tai nostetun Rudolf Bahron kirjan "Vaihtoehto". Sutela arvioi Bahron kirjaa ja käsityksiä tieteen, erityisesti taloustieteen kannalta. Erittelyssään Sutela päätyy hyvinkin kriittisiin näkökohtiin.

Julkaisimme edellisessä numerossamme (3/1978) Klaus Holzkampin artikkelin Marxin "Pääoman" ja psykologian tieteellistymisen suhteesta. Tässä numerossa jatkamme saman aihepiirin käsittelyä julkaisemalla Anja KoskiJänneksen ja Airi Hautamäen suorittamat Klaus Holzkampin ja Klaus Ottomeyerin haastattelut. Haastatteluissa paneudutaan materialistisen, tieteellisen, "kriittisen" psykologian kysymyksiin. Samoin haastatteluissa käsitellään erityisesti Ottomeyerin korostamaa ongelmaa marxilaisesta sosialisaatioteoriasta. 